\title{
Feeding Ten Billion and beyond: Why Technology May or May not Save Us
}

\author{
Abdirashid A Elmi* \\ Department of Environmental Technology Management, Kuwait University, Kuwait
}

Submission: April 10, 2017; Published: April 28, 2017

"Corresponding author: Abdirashid A Elmi, Department of Environmental Technology Management, College of Life Sciences, Kuwait University, P. 0. Box: 5969, Safat 13060, Kuwait, Tel: 2463-3280; Email: a.elmi@ku.edu.kw

\section{Introduction}

Human population growth is expected to reach 10.0 billion or so by 2050 [1], essentially adding a population the size of two India to the number of people living on the planet today. These additional billions of people will be seeking food, water and other environmental goods and services to satisfy their needs and wants from a planet already under enormous pressure. Furthermore, it is not only the number of people that matter in terms of resources consumption and waste generation, it is also the level affluence and how societies are organized that can shape the nature of the food challenges. Rapid urbanization is placing intense pressure on large areas of natural environment, especially environmentally sensitive lands such as fragile coastal ecosystems and arable lands.

There are concerns that food production may not keep pace with global population growth indefinitely for several reasons:

a. The land suitable to be converted into agricultural production is shrinking; b. Land conversion often incurs high environmental and social costs;

\section{c. Soil degradation and}

d. Water scarcity, especially in arid, hot regions. Despite these limiting factors, the world must produce more food for growing population not only from same amount of land, but a land that has been degraded and water resources stressed or near depletion point. Consequently, how the world where perhaps more than a quarter of its inhabitants live in abject poverty can feed and provide adequate social goods and services, all those being added every year, without further degrading quality of natural resources is a daunting challenge, considering also the changing planetary climate. The objective of this review is to synthesize farming and technological innovations to meet food security demands of growing world populations, while highlighting the concept of sustainability to safeguard against possible unintended consequences.

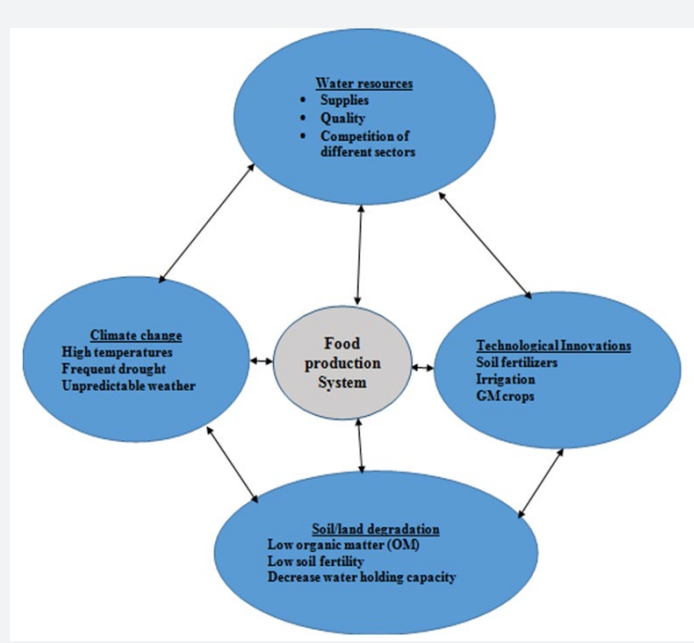

Figure 1: Interconnectedness of food production system with natural factors and farm level technology. Climate change can accelerate organic matter depletion which leads to a decline in soil fertility and soil water holding capacity. Technology can either destructively accelerate land degradation like heavy farm machinery. It can enhance irrigation efficiency. 
Conservation Tillage Systems as Sense of Agricultural Technology Revolution

Food production system is tightly linked to multiple natural and technological factors in a complex manner. Figure 1 graphically depicts the most salient factors. Globally, agriculture is the single largest use of land on the planet, occupying altogether about 38$40 \%$ of earth's terrestrial surface [2,3]. Much of the remaining parts of the terrestrial surface are covered by deserts, cities (urbanization), and lands unfit for agriculture [4]. Soil erosion is a major form of environmental degradation, reducing the fitness of soil and its productivity that may ultimately threaten the longterm sustainability of food production systems.

Concerns over declining soil productivity due to intensive tillage and erosion has brought about much interest in conservation tillage farming systems. Currently, No-tillage (NT) and various forms of Reduced Tillage (RT) practices are highly promoted as one of the key means through which soil quality and soil organic matter (SOM) can be maintained [5]. Recently, the concept of soil quality has gained prominence with respect to the sustainability of agriculture. Long-term experiments are needed to generate reliable information on how different management cropping systems may impact soil quality. However, only a few experiments have been conducted under the warm climatic conditions and sandy soils of the southeastern USA. Soil quality is increasingly conceptualized as the major linkage between agricultural conservation management strategies and achievement of the major goals of sustainable agriculture.

An obvious conclusion from this brief review of farming innovation methods is that the new paradigm of agriculture (best management practices; BMPs) may protect one resource at the expense of the other. This is a clear indication that the selection of BMPs for a given region depends not only on the physical and managerial characteristics of the farm, but also on the objectives and priorities of the parties involved. Balancing conflicting agronomic and environmental implications brought by the expansion of conservation tillage systems poses a new challenge. There is an urgent need for this remarkable shift from conventional tillage (CT) systems to various forms of conservation tillage systems to be investigated more thoroughly in relation to long-term environmental sustainability in light of divergent priorities.

\section{Tillage Effects on Crop Yield}

The adoption of new production technology by farmers always involves a degree of risk and uncertainty concerning its impact on economic output. The decision to change production technology is based on many factors. Farmers risk perceptions, level of managerial expertise, and local climate condition have all been identified as important factors affecting farmer's choice among farming systems [6]. Profits are what a producer looks at when deciding on a management practice and it isn't always as simple as replacing tillage costs with herbicide costs. Other factors, such as rotations, equipment, farm size, and government programs influence the bottom economic line.

Moving forward, tillage effects on crop yields depend on cropping systems including amount and characteristics of crop residue, soil type, and local climatic conditions. There are numerous reports comparing the effects of NT practices with RT and CT systems for corn production, most of them concluding that NT or RT can improve crop yields. This may be attributed in part to the higher moisture content often found in NT soils that can benefit crops during low rainfall periods. However, in cool and wet climate regions, soil warming in spring and seedling emergence may be delayed in systems that leave high levels of residue. Some early studies [7] reported that the lowest wheat grain yield was obtained in fields under NT and that yield was inversely related to the amount of crop residue cover on the field prior to planting [8]. divergent that increased profits associated with (NT) and (RT) are attributed to yield increase, reduced production costs such as fuel and labor. Putting all together, yield benefits associated with the continuous use of conservation tillage take a relatively long time to materialize.

This summary of available data suggests that no clear consensus emerges concerning the effects of conservation tillage on crop yields relative to conventional tillage. Development of production recommendations from short-term tillage studies is hampered by year-to-year variation in results which may mask the real impact of the tillage system being evaluated. To accurately evaluate the benefits and disadvantages of RT and NT systems, it is important to examine long-term impacts of these systems.

\section{Water Resources: Improved Irrigation Technology}

The agricultural sector, which consumes close to $90 \%$ of the water in certain places like the Gulf region [9], is currently coming under extreme pressure from multiple directions. The world will be confronted with even more severe water shortages as temperature rises due to global warming according to a recent and widely publicized study [10]. Inevitably, this will lead to an intense competition for water among different sectors, most likely, impeding renewed efforts for food security. Managing these competing demands in a way consistent with the principles of sustainability is one of the greatest challenges facing today's society.

Worldwide, water efficiency in irrigation tends to be low, with averages in the range of $25-50 \%$ [11]. Furthermore, in arid regions water productivity is far below its potential and there is a room for improved efficiency. Measures that reduce evaporation can generate real water savings in the Gulf region where evaporative losses from the commonly used sprinkler irrigation systems are excessively high. Modernized irrigation technology needs to be adopted to achieve better irrigation efficiency and, therefore, saving water in response declining water supply, competing demands, or a combination of these 
and other factors. The adoption of improved technologies and management practices whose primary objective is to apply the right amount of water at the right time is gaining growing popularity worldwide. However, such a bold move requires training to acquire new skills. Unlike presently used irrigation techniques (sprinkler), investing in water saving technologies can boost crop productivity per unit cropland. On the hand, promotion of conventional crops, such as date palms, which are tolerant to harsh soil and hot climatic conditions coupled with water saving/efficient techniques, can help to achieve food security goals.

\section{Food Production Systems and Climate Change}

Within the context of managing the commons, [12] published an enormously influential article in which it did no good for only one person to limit his sheep grazing. Earth atmosphere is today's commons metaphor, while countries in their race to maximize economic development has dumped huge quantities of heat trapping gases into the atmosphere, leading to a discernible change in the global climate system. Despite recent setback by US presidential election, climate change's profile has never been higher in the agenda. This is because the consequences of climate change - rising sea levels, severe flooding, droughts, etc. pose serious threats ranging from colossal shortages of essential resources to a massive population movement (environmental refugees) leading to rising tensions and armed conflicts in fragile regions. Climate change affects food production mainly through water resources availability and land degradation.

As the food system becomes increasingly globalized, more extreme weather will pressure food security in the coming decades. Commodity prices will become more volatile as food production is disrupted. Furthermore, what any country does within its borders in food production and management has implications for the entire world. For example, food importing countries depend on the political, environmental, and economic situations prevailing in the exporting countries that might choose or be forced to alter the supply of food available to the market [13]. For example, following drought and wildfires in 2010, Russia imposed a temporary ban on wheat exports for concern of domestic food security. Similar situations also emerged during more recent food crisis of 2007/2008, when food price spiking caused governments of major exporting countries to impose restrictions and/or bans on exports for fear of food shortages $[14,15]$. For net food importing countries, such episodes represent an existential threat to national food security.

\section{Can Technology Salvage the Situation?}

Undoubtedly, as a result of agricultural technological innovations during last century, agricultural productivity has increased substantially to keep pace with rapidly growing population. Unfortunately however, the benefits derived from more efficient food production system have been accompanied with a wide range of environmental and social costs. Efforts in innovative agricultural practices is not yet complete as the promotion of genetically modified (GM) crops, arguably one of the latest technological innovations has shown, with largely unknown and potentially harmful effects on human health and the environment. I would argue that lack of complete knowledge about the potential unintended consequences should not be interpreted as safety. The reason for this argument is simple: there is no record in human history in which innovation has had only benign consequences for the natural environment since industrial revolution.

\section{Concluding Remarks}

Sustainable agriculture has attracted much attention in recent years. The objective of agriculture has always been to feed populations. While this objective is still vital and necessary, it alone is not sufficient, and a number of other objectives, including minimizing adverse environmental impacts, must now be met. The need to identify best management practices that will ensure the continued productivity of agricultural lands while avoiding or minimizing adverse environmental impacts is being recognized. In light of diminishing environmental resources, meeting the needs of large additional number of human population will not be an easy task. Recognition of this simple fact and making it an integral part in the quest for solutions will energize the efforts of finding sustainable future.

\section{References}

1. UNFPA (2014) World population trends.

2. FAO (2015) Water for Food Security and Nutrition, A Report by the High Level Panel of Experts on Food Security and Nutrition of the Committee on World Food Security.

3. Ramankutty N, Evan AT, Monfreda C, Foley JA (2008) Farming the planet: 1. Geographic distribution of global agricultural lands in the year 2000. Global Biogeochemstry Cycle 22: GB1003.

4. FAO (2012) Towards the future we want: end hunger and make the transition to sustainable agricultural and food systems.

5. Karlen DL, Andrews SS, Doran JW (2001) Soil quality: Current concepts and applications. Advances in Agronomy 74: 1-40.

6. Uri ND (1999) Factors affecting the use of conservation tillage in the United States. Water Air\& Soil Pollution 116(3): 621-638.

7. Lindwall CW, Anderson DT (1981) Agronomic evaluations of minimum tillage systems for summerfallow in southern Alberta. Canadian Journal of Plant Science 61: 247-253.

8. Hussain I, Olso KR, Ebelhar SA (1999) Long term tillage effects on soil chemical properties and organic matter fractions. Soil Science Society America Journal 63(5): 1335-1341.

9. IFAD (2009) Fighting water scarcity in the Arab countries. Rome, Italy.

10. Pal J S, Eltahir EAB (2016) Future temperature in southwest Asia projected toexceed a threshold for human adaptability. Nature Climate Change 6: 197-200.

11. Tiwari D, Dinar A (2001) Role and Use of Economic Incentives in Irrigated Agriculture.

12. Hardin G (1968) The Tragedy of the Commons. Science: 162(3859): 1243-1248

13. Fader M, Gerten D, Krause M, Lucht W, Cramer W (2013) Spatial decoupling of agricultural production and consumption: quantifying 
dependences of countries on food imports due to domestic land and water constraints. Environmental Research Letters 8: 1-15.

14. Trostle R, Marti D, Rosen S, Westcott P (2011) Why Have Food Commodity Prices Risen Again? Washington, USA, p. 29.
15. Maetz M, Aguirre M, Kim S, Matinroshan Y, Pangrazio G, et al. (2011) Food and agricultural policy trends after the 2008 food security crisis. Renewed attention to agricultural development Resources for Policy Making. Module 125, Rome, Italy.

\section{Your next submission with Juniper Publishers will reach you the below assets}

- Quality Editorial service

- Swift Peer Review

- Reprints availability

- E-prints Service

- Manuscript Podcast for convenient understanding

- Global attainment for your research

- Manuscript accessibility in different formats

( Pdf, E-pub, Full Text, Audio)

- Unceasing customer service

Track the below URL for one-step submission https://juniperpublishers.com/online-submission.php 